\title{
Regulation of Collecting Tubule Adenosine Triphosphatases by Aldosterone and Potassium
}

\author{
Somchai Eiam-Ong, Neil A. Kurtzman, and Sandra Sabatini \\ Division of Nephrology, Departments of Internal Medicine and Physiology, Texas Tech University \\ Health Sciences Center, Lubbock, Texas 79430
}

\begin{abstract}
To examine the precise role of potassium and aldosterone on acid-base composition and on collecting tubule ATPases, glucocorticoid-replete adrenalectomized rats were replaced with zero, physiological, or pharmacological doses of aldosterone and were fed varying potassium diets to produce hypokalemia, normokalemia, or hyperkalemia. Radiochemical measurement of ATPase activities showed that collecting tubule $\mathrm{H} / \mathrm{K}$ ATPase changed inversely with potassium and not with aldosterone whereas H-ATPase changed directly with aldosterone but not with potassium. When both enzymes changed in the same direction, alterations in acid-base composition were profound; however, when these two acidifying enzymes changed in opposite directions or when only one enzyme changed, the effect on acid-base balance was modest. Serum bicarbonate was $\sim 45$ meq/liter when aldosterone was high and potassium was low; it was only $29 \mathrm{meq} /$ liter when aldosterone was high but potassium was normal or when aldosterone was normal and potassium was low. Our observations may help explain the metabolic alkalosis of primary aldosteronism in which aldosterone excess and hypokalemia are combined and the metabolic acidosis of aldosterone deficiency in which hypoaldosteronism and hyperkalemia are paired. The present study also demonstrated that aldosterone plays the major role in controlling $\mathrm{Na} / \mathrm{K}$-ATPase activity in cortical collecting tubule. Hypokalemia stimulates $\mathrm{Na} / \mathrm{K}$-ATPase activity in the medullary collecting tubule; this stimulatory effect of hypokalemia supports the hypothesis that the enzyme is present on the apical membrane at this site. ( $J$. Clin. Invest. 1993. 91:2385-2392.) Key words: renal proton ATPases • acidification mechanisms $\bullet$ hyperaldosteronism • luminal $\mathrm{Na} / \mathrm{K}$-ATPase $\bullet$ potassium reabsorption
\end{abstract}

\section{Introduction}

Potassium and aldosterone (Aldo) ${ }^{1}$ exert major effects on collecting tubule function (1-3). When potassium depletion is accompanied by aldosterone excess both acidification and sodium transport are stimulated. Conversely, when potassium

A portion of this study was presented at the annual meeting of the Association of American Physicians, Baltimore, MD, 1-4 May 1992, and published in abstract form (1992. Clin. Res. 40:218).

Address correspondence to Neil A. Kurtzman, M.D., Department of Internal Medicine, Texas Tech University Health Sciences Center, 3601 4th Street, Lubbock, TX 79430.

Received for publication 2 September 1992 and in revised form 28 December 1992.

J. Clin. Invest.

(C) The American Society for Clinical Investigation, Inc.

$0021-9738 / 93 / 06 / 2385 / 08 \quad \$ 2.00$

Volume 91, June 1993, 2385-2392 excess is accompanied by aldosterone deficiency, acidification and sodium transport are inhibited $(4,5)$.

In the collecting tubule, sodium transport is modulated by the enzyme, $\mathrm{Na} / \mathrm{K}$-adenosine triphosphatase (ATPase) (1). This enzyme is thought to be localized solely to the basolateral membrane. Acidification appears to be controlled by two renal proton-translocating ATPases, an electrogenic H-ATPase inhibitable by $N$-ethylmaleimide (NEM) (6) and an electroneutral H/K-ATPase similar to that of gastric mucosa, inhibitable by $\mathrm{SCH} 28080$ and vanadate $(7,8)$. Previous work has shown that aldosterone stimulates collecting tubule H-ATPase activity (9-11), but the effect of aldosterone on the renal $\mathrm{H} / \mathrm{K}$ ATPase enzyme is not known. Potassium depletion enhances the activity of the H/K-ATPase; the effect of potassium depletion on H-ATPase activity is controversial $(7,8,12,13)$. In the cortical segment of the collecting tubule, aldosterone enhances $\mathrm{Na} / \mathrm{K}-\mathrm{ATPase}$ activity whereas in the medullary segment, potassium depletion stimulates its activity (14-17). The interrelation between these two variables is not yet clear. Obviously, changing potassium metabolism alters aldosterone release, and a change in aldosterone secretion alters potassium homeostasis (3).

This study was designed to examine the effects of altering potassium and aldosterone metabolism under controlled conditions on both acid-base composition and ATPase activities in rat cortical collecting tubule (CCT) and medullary collecting tubule (MCT). In these experiments we did not allow plasma potassium to change as the plasma aldosterone levels were altered and vice versa. Consequently, the direct effects of potassium and of aldosterone on enzyme activities could be discerned.

\section{Methods}

Adrenalectomized rats (Table I). 10 experimental groups of male albino Sprague-Dawley rats (150-200 g) were designed, but only nine groups could be studied (Table I). After nembutal anesthesia ( 50 $\mathrm{mg} \cdot \mathrm{kg}^{-1} \cdot$ body $\mathrm{wt}^{-1}$, i.p.), animals underwent either a sham adrenalectomy (group 1) or were bilaterally adrenalectomized (ADX) (groups 2-9). An osmotic minipump (Alzet 2002; Alza Corporation, Palo Alto, CA) for hormone replacement was implanted subcutaneously in the intrascapular region of each rat at the time of adrenalectomy. Each ADX rat received dexamethasone $1.4 \mu \mathrm{g} \cdot 100 \mathrm{~g}_{\text {body }} \mathrm{wt}^{-1} \cdot \mathrm{d}^{-1}$ as maintenance glucocorticoid replacement; polyethylene glycol 400 was used as diluent for the hormone. The daily dose of aldosterone replacement was zero ( 0 Aldo); $1 \mu \mathrm{g} / 100 \mathrm{~g}$ body wt ( N Aldo); or $50 \mu \mathrm{g} / 100 \mathrm{~g}$ body wt ( $\uparrow$ Aldo). After recovery from surgery the rats were fed a diet containing varying potassium concentrations (ICN Pharmaceuticals, Inc.,

1. Abbreviations used in this paper: Aldo, aldosterone; ADX, adrenalectomized; ATPase, adenosine triphosphate; CCT, cortical collecting tubule; MCT, medullary collecting tubule; N, normal concentration; NEM, $N$-ethylmaleimide; $\uparrow$, high concentration; $\downarrow$, low concentration. 
Table I. Experimental Groups in Rats

\begin{tabular}{cl}
\hline Group & \multicolumn{1}{c}{ Treatment } \\
\hline 1 & Control, (sham ADX) \\
2 & ADX, N Aldo, N K \\
3 & ADX, N Aldo, $\downarrow$ K \\
4 & ADX, N Aldo, $\uparrow$ K \\
5 & ADX, 0 Aldo, N K \\
6 & ADX, 0 Aldo, $\downarrow$ K \\
7 & ADX, 0 Aldo, $\uparrow$ K \\
8 & ADX, $\uparrow$ Aldo, N K \\
9 & ADX, $\uparrow$ Aldo, $\downarrow$ K \\
$10^{*}$ & ADX, $\uparrow$ Aldo, $\uparrow \mathrm{K}$ \\
\hline
\end{tabular}

$n=6$ in each group; $\mathrm{N}$, normal. ${ }^{*}$ We were unable to induce hyperkalemia in animals replaced with a pharmacological dose of aldosterone (group 10). Thus, we could not study this group.

Costa Mesa, CA ) to produce hypokalemia, normokalemia, or hyperkalemia.

Sham-operated controls received normal rat chow. To produce hyperkalemia, the animals, regardless of aldosterone status, were fed a diet that contained 15 times the amount of potassium but was otherwise identical to a normal chow diet (18). Irrespective of aldosterone status, the animals subjected to hypokalemia received a potassium-deficient diet containing $1.5 \mathrm{meq} \mathrm{K} / \mathrm{kg}$. The 0 Aldo and $\mathrm{N}$ Aldo groups were fed a normal diet to produce and maintain plasma potassium. The $\uparrow$ Aldo group subjected to normokalemia was fed a high potassium content diet because of a tendency to develop hypokalemia with a normal chow diet. We were unable to induce hyperkalemia in the $\uparrow$ Aldo rats (see Table I), thus we could not study this group. All animals were given $0.3 \% \mathrm{NaCl}$ to drink ad libitum.

The influence of varying aldosterone and potassium levels on acidbase composition and on the activity of microdissected collecting tubule proton ATPases (H-ATPase and H/K-ATPase) and $\mathrm{Na} / \mathrm{K}$ ATPase was studied after $7 \mathrm{~d}$.

Adrenal intact rats. These studies examined ATPase activities and systemic acid-base composition during potassium depletion. The rats were divided into two groups control and $\downarrow$ potassium. Control rats were fed a normal potassium diet for $7 \mathrm{~d}(150$ meq K$+/ \mathrm{kg})$ whereas the $\downarrow \mathrm{K}$ group was fed a semisynthetic potassium-deficient diet containing $1.5 \mathrm{meq} \mathrm{K} / \mathrm{kg}$ for $7 \mathrm{~d}$. These animals were allowed free access to tap water.

On the day before each experiment the rats were placed in metabolic cages for a 24-h urine collection. On the day of the experiment, the animals were anesthetized as previously described (19) and blood samples were obtained from the aorta for measurement of $\mathrm{pH}, \mathrm{PCO}_{2}$, electrolytes, and hormones. Arterial $\mathrm{pH}, \mathrm{PCO}_{2}$ and urine and plasma electrolytes were measured by standard methods as previously described (20). Muscle potassium concentration was measured by atomic-absorption spectrophotometry as previously described (20). Plasma aldosterone concentration was determined by radioimmunoassay (COAT-A-COUNT ${ }^{\circledR}$; DPC, Los Angeles, CA).

Tubule microdissection and enzymatic measurements. Cortical and medullary collecting tubules were microdissected as previously described $(19,20)$. In brief, the left renal artery was cannulated and the kidney was perfused for $15 \mathrm{~min}$ in situ at a rate of $0.7 \mathrm{ml} / \mathrm{min}$ with a balanced salt solution containing $400 \mathrm{U} / \mathrm{ml}$ collagenase, $4^{\circ} \mathrm{C}, \mathrm{pH} 7.4$. The kidneys were then cut along the cortico-papillary axis and incubated in $3 \mathrm{ml}$ of collagenase-albumin containing Hanks' solution at $35^{\circ} \mathrm{C}$ for $12 \mathrm{~min}$. The tissues were continuously bubbled with compressed air ( $3 \mathrm{psi}$ ). After incubation, the pyramids were rinsed and segments of CCT and MCT were microdissected. (If H/K-ATPase activity was measured an additional step was performed to remove the extracellular potassium; nephron segments were incubated for $15 \mathrm{~min}$ at $37^{\circ} \mathrm{C}[\mathrm{pH} 7.4]$ in potassium-free buffer $(7,20)$. If the other enzymes were measured, this step was omitted $[9,16,19])$. The nephron segments were then permeabilized using a two-step hypotonic-hypothermic shock and ATPase activities were determined using $\gamma^{32} \mathrm{P}$-labeled ATP $\left(37^{\circ} \mathrm{C}, 15 \mathrm{~min}, \mathrm{pH} \mathrm{7.4}\right)$. H-ATPase, $\mathrm{H} / \mathrm{K}-\mathrm{ATPase}$, and $\mathrm{Na} / \mathrm{K}$ ATPase were measured by the radiochemical method of Doucet and Marcy (7) and Khadouri et al. (11,12) as subsequently described by us $(19,20)$.

$\mathrm{Na} / \mathrm{K}-\mathrm{ATPase}$ activity was measured as the ouabain-sensitive $\mathrm{Na}$ / $\mathrm{K}$-dependent ATPase. ATPase activity was first measured in buffer with the following composition (mM): $50 \mathrm{NaCl}, 5 \mathrm{KCl}, 10 \mathrm{MgCl}_{2}, 1$ EGTA, and 100 Tris $\cdot \mathrm{HCl}$. High specific activity $\left[\gamma^{32} \mathrm{P}\right]$ ATP $(2-10$ $\mathrm{Ci} / \mathrm{mmol})$ was added in tracer amounts $(10 \mathrm{nCi} / \mu \mathrm{l})$ to vanadium-free ATP $(12 \mathrm{mM})$. After incubation ( $15 \mathrm{~min})$, the reaction was stopped by placing the tubules on ice; this was followed immediately by the addition of $7 \mu \mathrm{l}$ of a $10 \%$ activated charcoal suspension in $5 \%$ trichloroacetic acid $\left(4^{\circ} \mathrm{C}\right)$. Activated charcoal was used to bind the unhydrolyzed ATP, and the labeled inorganic phosphate was separated under vacuum by rapid Millipore ${ }^{\star}$ (Millipore Corp., Bedford, MA) filtration coupled with a wash of $0.1 \%$ phosphate buffer $(1 \mathrm{ml}), \mathrm{pH} 6.0$, at $4^{\circ} \mathrm{C}$ To determine the ouabain-sensitive $\mathrm{Na} / \mathrm{K}-\mathrm{ATPase}$, sodium and potassium were replaced with $50 \mathrm{mM}$ Tris $\mathrm{HCl}$, and $2 \mathrm{mM}$ ouabain was added to the buffer. $\mathrm{Na} / \mathrm{K}$-ATPase activity is defined as the difference in activity found in the presence and absence of ouabain $(19,20)$.

H-ATPase activity was measured as the NEM-sensitive H-ATPase. ATPase was first measured in a sodium- and potassium-free buffer containing $150 \mathrm{mM}$ Tris $\mathrm{HCl}, 10 \mathrm{mM} \mathrm{MgCl}, 1 \mathrm{mM}$ EGTA, $2 \mathrm{mM}$ ouabain, $2 \mathrm{mM}$ sodium azide, $20 \mu \mathrm{g} / \mathrm{ml}$ oligomycin, and $12 \mathrm{mM}$ vanadium-free ATP. After incubation ( $15 \mathrm{~min}$ ), the reaction was stopped as described above. To determine NEM-sensitive ATPase, tubules were also incubated in a solution containing $2 \mathrm{mM}$ NEM. H-ATPase activity is defined as the difference in activity found in the presence and absence of $\operatorname{NEM}(19,20)$.

$\mathrm{H} / \mathrm{K}-\mathrm{ATPase}$ activity was measured as the SCH 28080-sensitive $\mathrm{H} / \mathrm{K}$-ATPase. ATPase activity was measured first in the sodium-free buffer containing $150 \mathrm{mM}$ Tris $\mathrm{HCl}, 10 \mathrm{mM} \mathrm{MgCl} 2,1 \mathrm{mM}$ EGTA, 2 $\mathrm{mM}$ ouabain, $2 \mathrm{mM}$ NEM, $2 \mathrm{mM}$ sodium azide, $20 \mu \mathrm{g} / \mathrm{ml}$ oligomycin, $4 \mathrm{mM} \mathrm{KCl}$, and $12 \mathrm{mM}$ vanadium-free ATP. To determine $\mathrm{H} / \mathrm{K}-$ ATPase activity, the tubules were incubated in a zero potassium buffer containing $200 \mu \mathrm{M}$ SCH 28080 . The concentration of SCH 28080 is greater than the two- to threefold that is needed to inhibit the enzyme under the above conditions. H/K-ATPase activity is defined as the difference in the activity found in the presence and the absence of potassium and SCH 28080 (20).

We and others have previously shown that the assays just described are performed under $V_{\max }$ conditions $(7,19-21)$. Enzyme activity is expressed as $\mathrm{pmol} / \mathrm{mm}$ tubule length per $\mathrm{h}$ of ATP hydrolyzed. All samples were run in triplicate or quadruplicate and appropriate corrections were made for blanks and the spontaneous hydrolysis of ATP.

Materials. All chemicals and reagents were obtained from Sigma Chemical Co. (St. Louis, MO) and were of highest purity. Radiolabeled ATP was obtained from New England Nuclear (Boston, MA).

Statistics. Statistical significance was assessed using the Student's $t$ test or analysis of covariance, where appropriate, with $P$ values of $\leq 0.05$ being significant.

\section{Results}

Metabolic data for adrenalectomized rats (Tables II and III). Plasma sodium was similar in all experimental groups. As expected, hypokalemia developed in groups 3,6 , and 9 whereas a normal plasma potassium was observed in groups 2,5 , and 8 . In groups 4 and 7 hyperkalemia was apparent. The changes in fractional potassium excretion and muscle potassium occurred in the same direction as those seen with the plasma potassium. 
Table II. Metabolic Parameters in Adrenalectomized Rats

\begin{tabular}{|c|c|c|c|c|c|c|c|}
\hline \multirow[b]{2}{*}{ Group \# } & \multicolumn{2}{|c|}{ Body weight } & \multirow[b]{2}{*}{$\mathbf{P}_{\mathbf{K}}$} & \multirow[b]{2}{*}{$\mathbf{P}_{\mathrm{Na}_{\mathbf{2}}}$} & \multirow[b]{2}{*}{$\mathrm{FE}_{\mathbf{k}}$} & \multirow[b]{2}{*}{ Muscle potassium } & \multirow[b]{2}{*}{$\mathrm{CCr}$} \\
\hline & Day 1 & Day 8 & & & & & \\
\hline & \multicolumn{2}{|c|}{$g$} & \multicolumn{2}{|c|}{ meq/liter } & $\%$ & $m e q / g d r y w t$ & $\mathrm{ml} \cdot \mathrm{min}^{-1} \cdot 100 \mathrm{~g}$ body $\mathrm{wt}^{-1}$ \\
\hline 1. Sham & $149 \pm 3$ & $185 \pm 3$ & $4.1 \pm 0.2$ & $145 \pm 2$ & $33 \pm 2$ & $0.44 \pm 0.01$ & $0.94 \pm 0.08$ \\
\hline 2. N Aldo, N K & $147 \pm 2$ & $183 \pm 3$ & $4.1 \pm 0.2$ & $143 \pm 6$ & $31 \pm 2$ & $0.43 \pm 0.01$ & $0.90 \pm 0.09$ \\
\hline 3. N Aldo, $\downarrow$ K & $152 \pm 2$ & $184 \pm 2$ & $2.3 \pm 0.2^{\ddagger}$ & $142 \pm 3$ & $1 \pm 0.8^{\ddagger}$ & $0.30 \pm 0.02^{*}$ & $0.89 \pm 0.06$ \\
\hline 4. $\mathrm{N}$ Aldo, $\uparrow \mathrm{K}$ & $152 \pm 2$ & $142 \pm 2^{*}$ & $6.0 \pm 0.4^{\ddagger}$ & $146 \pm 4$ & $104 \pm 13^{\ddagger}$ & $0.48 \pm 0.01$ & $0.88 \pm 0.08$ \\
\hline 5. 0 Aldo, $\mathrm{N} \mathrm{K}$ & $149 \pm 4$ & $160 \pm 5^{*}$ & $4.2 \pm 0.2$ & $146 \pm 2$ & $34 \pm 2$ & $0.43 \pm 0.01$ & $0.89 \pm 0.04$ \\
\hline 6. 0 Aldo, $\downarrow K$ & $148 \pm 5$ & $160 \pm 4^{*}$ & $2.8 \pm 0.2^{\ddagger}$ & $147 \pm 3$ & $2 \pm 0.6^{\ddagger}$ & $0.34 \pm 0.02^{*}$ & $0.88 \pm 0.05$ \\
\hline 7. 0 Aldo, $\uparrow \mathrm{K}$ & $152 \pm 4$ & $128 \pm 3^{\ddagger}$ & $6.4 \pm 0.7^{\ddagger}$ & $147 \pm 2$ & $85 \pm 6^{\ddagger}$ & $0.49 \pm 0.01$ & $0.86 \pm 0.08$ \\
\hline 8. $\uparrow$ Aldo, N K & $149 \pm 5$ & $178 \pm 2$ & $4.4 \pm 0.2$ & $146 \pm 3$ & $102 \pm 12^{\ddagger}$ & $0.45 \pm 0.01$ & $0.89 \pm 0.06$ \\
\hline 9. $\uparrow$ Aldo, $\downarrow \mathrm{K}$ & $152 \pm 4$ & $181 \pm 6$ & $2.2 \pm 0.2^{\ddagger}$ & $148 \pm 4$ & $2 \pm 0.6^{\ddagger}$ & $0.30 \pm 0.03^{*}$ & $0.88 \pm 0.04$ \\
\hline
\end{tabular}

$\mathrm{FE}_{\mathrm{K}}$, fractional potassium excretion; $\mathrm{CCr}$, creatinine clearance. $n=6$ in each group. ${ }^{*} P<0.05,{ }^{\ddagger} P<0.005$ vs. sham.

There was no significant difference in creatinine clearance in any of the experimental groups.

Plasma aldosterone levels averaged $\sim 5 \mathrm{ng} / \mathrm{dl}$ in all animals receiving physiological hormone replacement (i.e., groups 2-5), values comparable those measured in normal unstressed animals (Table III). In the 0 Aldo rats (i.e., groups 5-7), plasma aldosterone was undetectable. By contrast, aldosterone levels were markedly elevated in rats receiving with pharmacological doses of the mineralocorticoid (i.e., groups 8 and 9). The moderately high aldosterone level in intact control rats (i.e., group 1 ) likely reflects the stress of surgery and anesthesia.

$H / K-A T P a s e$ activity (Fig. 1). In normokalemic rats (groups 2, 5, and 8), regardless of the aldosterone level, $\mathrm{H} / \mathrm{K}$ ATPase activity in both CCT and MCT was similar to that of control. In hypokalemic rats (groups 3, 6, and 9), however, enzyme activity was markedly increased compared with control. This increase was noted regardless of the aldosterone status. Compared with control, the percent increase in $\mathrm{H} / \mathrm{K}$ ATPase activity in CCT averaged $82 \pm 6.8,88 \pm 9.0$, and $90 \pm 8.9 \%$ in the 0 Aldo, $N$ Aldo, and $\uparrow$ Aldo groups, respectively $(P<0.005)$; in the MCT, the percent increase averaged $92 \pm 8.6,100 \pm 11.7$, and $94 \pm 9.2 \%$ in the 0 Aldo, the $\mathrm{N}$ Aldo, and the $\uparrow$ Aldo rats, respectively $(P<0.005)$.

In both of the hyperkalemic groups, H/K-ATPase activity was markedly decreased (groups 4 and 7). This decrease was noted regardless of the aldosterone status of the animals. En-

Table III. Plasma Aldosterone Level in Adrenalectomized Rats

\begin{tabular}{lccc}
\hline Group & $\downarrow \mathrm{K}$ & $\mathrm{N} \mathrm{K}$ & $\uparrow \mathrm{K}$ \\
\hline 0 Aldo & ND & ND & ND \\
N Aldo & $5.50 \pm 0.48$ & $5.28 \pm 0.46$ & $5.60 \pm 0.38$ \\
$\uparrow$ Aldo & $282.00 \pm 21.40^{*}$ & $268.00 \pm 21.91^{*}$ & Not done \\
Sham & - & $33.40 \pm 1.60$ & -
\end{tabular}

Plasma aldosterone is expressed as $\mathrm{ng} / \mathrm{dl} ; \downarrow \downarrow \mathrm{K}$, hypokalemia; $\mathrm{N} \mathrm{K}$, normokalemia; $\uparrow \mathrm{K}$, hyperkalemia; ND, not detectable. $n=6$ in each group. ${ }^{*} P<0.005$ vs. $\mathrm{N}$ Aldo with similar potassium level. zyme activity in CCT and MCT was $69 \pm 1.6$ and $65 \pm 2.1 \%$ of control, respectively, in the 0 Aldo group $(P<0.005)$. In the $\mathrm{N}$ Aldo group, it was $67 \pm 2.1 \%$ of control in CCT and $61 \pm 3.1 \%$ of control in MCT $(P<0.005)$. There was no significant difference in $\mathrm{H} / \mathrm{K}$-ATPase activity at different aldosterone levels in those animals having the same potassium concentration.

H-ATPase activity (Fig. 2). In rats with physiological aldosterone replacement ( $\mathrm{N}$ Aldo groups), H-ATPase activities were not significantly different from the control at any level of
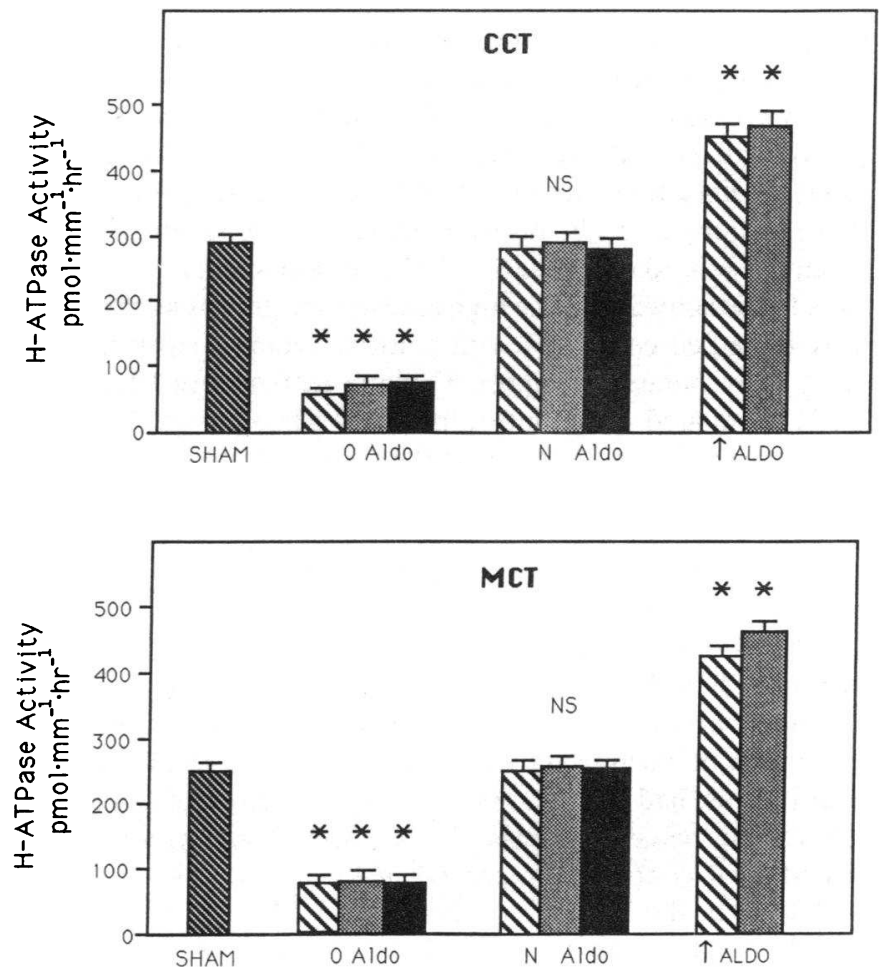

Figure 1. The effect of aldosterone and potassium on $\mathrm{H} / \mathrm{K}$-ATPase activity in CCT and MCT in adrenalectomized rats. 0 Aldo, no aldosterone replacement; $N$ Aldo, $1 \mu \mathrm{g}$ aldosterone $\cdot 100 \mathrm{~g}^{\text {body }} \mathrm{wt}^{-1} \cdot \mathrm{d}^{-1}$; $\uparrow$ Aldo, $50 \mu \mathrm{g}$ aldosterone $\cdot 100 \mathrm{~g}$ body $\mathrm{wt}^{-1} \cdot \mathrm{d}^{-1} ;{ }^{*} P<0.005$ vs. SHAM animals. NS, not significant. Hypokalemia, white hatched bars; normokalemia, gray stippled bars; hyperkalemia, black bars. 

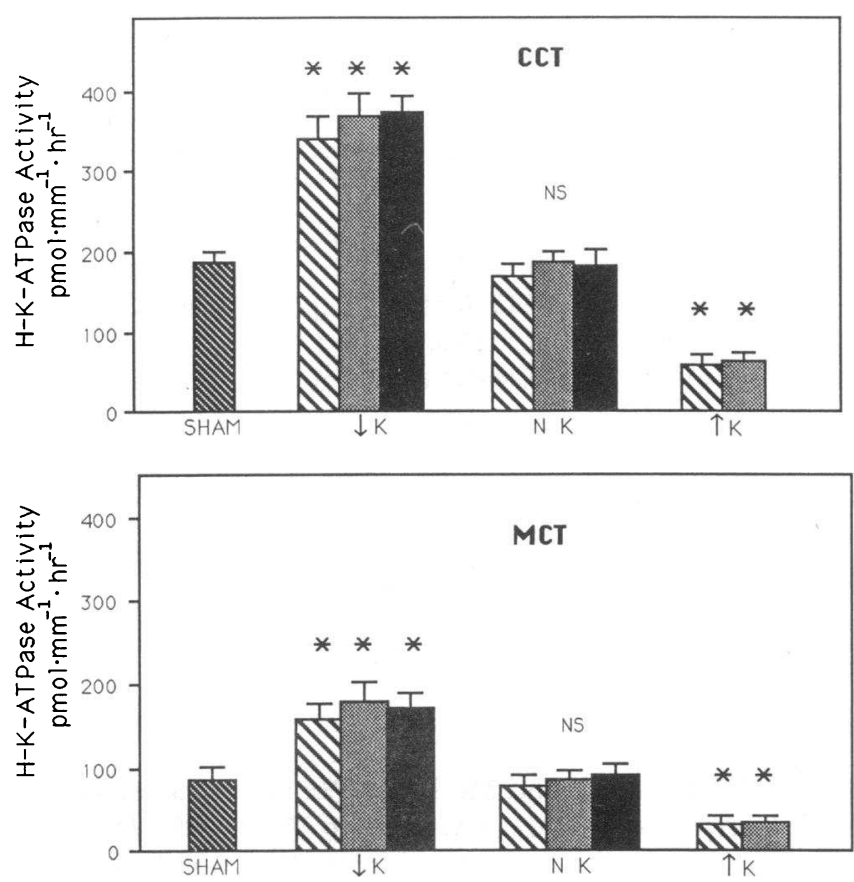

Figure 2. The effect of aldosterone and potassium on H-ATPase activity in CCT and MCT in adrenalectomized rats. $\downarrow K$, hypokalemia; $N K$, normokalemia; $\uparrow K$, hyperkalemia; ${ }^{*} P<0.005$ vs. sham animals. $N S$, not significant. 0 Aldo replacement, white hatched bars; 1

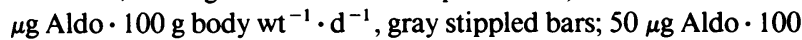
$\mathrm{g}$ body $\mathrm{wt}^{-1} \cdot \mathrm{d}^{-1}$, black bars.

serum potassium. By contrast, 0 Aldo rats had a marked reduction in enzyme activity regardless of potassium status. The percent decrease in the enzyme activity in CCT and MCT compared with control averaged $70 \pm 1.5$ and $70 \pm 1.1 \%$, respectively, in the $\downarrow \mathrm{K}$ groups $(P<0.005)$. In the $\mathrm{N} \mathrm{K}$ groups it was $70 \pm 2.0$ and $69 \pm 2.1 \%$, respectively $(P<0.005)$. In the $\uparrow \mathrm{K}$ groups it was $70 \pm 0.7$ and $69 \pm 0.8 \%$, respectively $(P<0.005)$. $\mathrm{H}$-ATPase activities in the high aldosterone groups were markedly increased compared with control, again independent of total body potassium stores. Enzyme activities in CCT and MCT compared with control increased $55 \pm 6.4$ and $86 \pm 6.9 \%$, respectively, in the $\downarrow \mathrm{K}$ groups $(P<0.005)$ whereas in the N K groups it increased by $61 \pm 3.0$ and $91 \pm 3.4 \%$, respectively $(P$ $<0.005)$. There was no significant difference in H-ATPase activity at different potassium levels in those animals having the same aldosterone values.

$\mathrm{Na} / \mathrm{K}$-ATPase activities (Fig. 3). Na/K-ATPase activities in the CCT of $\mathrm{N}$ Aldo rats with $\mathrm{N} \mathrm{K}$ and $\uparrow \mathrm{K}$ were similar to control whereas the $\downarrow$ K group had a small, but significant reduction in enzyme activity. 0 Aldo rats, regardless of potassium status, had about a $50 \%$ reduction in enzyme activity in $\mathrm{CCT}$. The percent decrease in $\mathrm{Na} / \mathrm{K}$-ATPase activity compared with control averaged $64 \pm 6.1 \%$ in the $\downarrow \mathrm{K}$ group ( $P$ $<0.01)$. In the $\mathrm{N} \mathrm{K}$ group there was a $52 \pm 8.3 \%$ decrease in $\mathrm{Na} / \mathrm{K}-\mathrm{ATPase}$ activity $(P<0.01)$ and in the $\uparrow \mathrm{K}$ group there was a $50 \pm 8.1 \%$ decrease $(P<0.01)$. Thus, enzyme activity in CCT of the $\downarrow K$ group was significantly lower than in the N K or the $\uparrow \mathrm{K}$ groups $(P<0.05)$.

In the CCT of the $\uparrow$ Aldo rats, irrespective of potassium status, $\mathrm{Na} / \mathrm{K}$-ATPase activities were enhanced by $\sim 100 \%$ of control $(91 \pm 8.5 \%$ in the $\downarrow K$ group and $108 \pm 8.1 \%$ in the $N K$
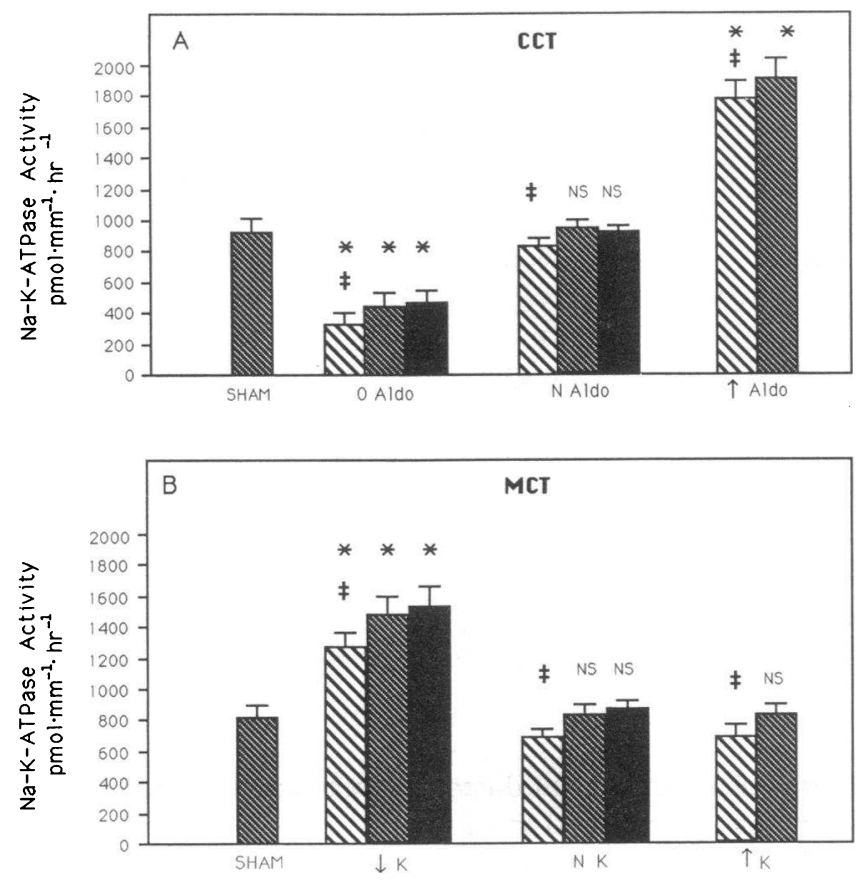

Figure 3. The effect of aldosterone and potassium on $\mathrm{Na} / \mathrm{K}$-ATPase activity in CCT $(A)$ and MCT $(B)$. In CCT Na/K-ATPase activities were studied with different aldosterone levels. Hypokalemia, white hatched bars; normokalemia, gray shaded bars; Hyperkalemia, black bars. ${ }^{*} P<0.005$ vs. sham animals ${ }^{\ddagger} P<0.05$ vs. normokalemic animals at same aldosterone status. In MCT, Na/K-ATPase activities were studied with different potassium levels. 0 Aldo replacement, white hatched bars; $1 \mu \mathrm{g}$ Aldo $\cdot 100 \mathrm{~g}$ body wt ${ }^{-1} \cdot \mathrm{d}^{-1}$, gray shaded bars; $50 \mu \mathrm{g}$ Aldo $\cdot 100 \mathrm{~g}$ body wt ${ }^{-1} \cdot \mathrm{d}^{-1}$, black bars. ${ }^{*} P<0.005$ vs. sham animals ${ }^{\ddagger} P<0.05$ vs. normokalemic animals at same potassium level.

group) $(P<0.01)$. Again, the enzyme activity in the $\downarrow \mathrm{K}$ group was significantly lower than in the $\mathrm{N} \mathrm{K}$ group $(P<0.05)$.

In MCT, hypokalemia, irrespective of aldosterone activity, enhanced $\mathrm{Na} / \mathrm{K}$-ATPase activity. The percent increase was $67 \pm 4.5 \%$ in the 0 Aldo group, $81 \pm 8.9 \%$ in the $\mathrm{N}$ Aldo group, and $84 \pm 8.5 \%$ in $\uparrow$ Aldo $(P<0.005)$. In the $\uparrow \mathrm{K}$ animals, however, enzyme activity was similar to that of control if the animals were replaced with physiological amounts of aldosterone. It should be noted that $\mathrm{Na} / \mathrm{K}$-ATPase activity in 0 Aldo rats, irrespective of potassium level, was lower than those of the $N$ Aldo group and the $\uparrow$ Aldo group at the same potassium level.

Alterations in acid-base composition (Table IV). When the relationship between acid-base parameters and the changes in aldosterone and potassium were assessed ( Table IV), interesting correlations were observed. When both aldosterone excess and hypokalemia were present simultaneously, a condition under which both renal proton ATPases (H-ATPase and H/K-ATPase) were markedly stimulated, severe metabolic alkalosis occurred ( plasma $\mathrm{HCO}_{3}^{-}=45.9 \pm 2.0$ vs. $23.9 \pm 1.1 \mathrm{meq} /$ liter in sham controls, $P<0.005$ ). By contrast, metabolic acidosis resulted only when both enzymes were inhibited; this occurred only when aldosterone deficiency ( 0 Aldo) was associated with hyperkalemia (plasma $\mathrm{HCO}_{3}^{-}=16.8 \pm 1.0$ vs. $23.9 \pm 1.1 \mathrm{meq} /$ liter in sham controls, $P<0.005)$. When one enzyme fell and the other remained unchanged (as in N Aldo $\uparrow$ $\mathrm{K}$ or 0 Aldo $\mathrm{N} \mathrm{K}$ ), modest changes in bicarbonate were ob- 
Table IV. The Effect of Aldosterone and Potassium on Plasma Bicarbonate in Adrenalectomized Rats

\begin{tabular}{lccc}
\hline Group & 0 Aldo & N Aldo & $\uparrow$ Aldo \\
\hline$\downarrow \mathrm{K}$ & $20.8 \pm 0.6^{*}$ & $29.3 \pm 1.6^{*}$ & $45.9 \pm 2.0^{*}$ \\
$\mathrm{~N} \mathrm{~K}$ & $20.3 \pm 0.5^{*}$ & $24.2 \pm 1.0$ & $29.7 \pm 1.5^{*}$ \\
$\uparrow \mathrm{K}$ & $16.8 \pm 1.0^{\ddagger}$ & $22.4 \pm 0.8$ & Not done \\
Sham & - & $23.9 \pm 1.1$ & - \\
\hline
\end{tabular}

Plasma bicarbonate is expressed as meq/liter; 0 Aldo, no aldosterone replacement; $\mathrm{N}$ Aldo $=1 \mu \mathrm{g}$ aldosterone $\cdot 100 \mathrm{~g}$ body $\mathrm{wt}^{-1} \cdot \mathrm{d}^{-1} ; \uparrow$

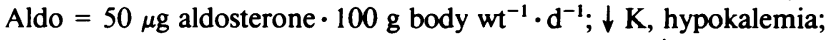
N K, normokalemia; $\uparrow \mathrm{K}$, hyperkalemia. ${ }^{*} P<0.05,{ }^{\ddagger} P<0.005$ vs. sham control animals.

served. In the former plasma $\mathrm{HCO}_{3}^{-}$was $22.4 \pm 0.8 \mathrm{meq} /$ liter whereas in the latter it was $20.3 \pm 0.5 \mathrm{meq} /$ liter. In the 0 Aldo $\mathrm{N}$ $\mathrm{K}$ group there was a greater fall in plasma bicarbonate than there was in the high $\mathrm{N}$ Aldo $\uparrow \mathrm{K}$ group. When one enzyme fell and the other increased, as in 0 Aldo $\downarrow K$, the change in bicarbonate concentration was not significant. When one enzyme increased, but the other was unchanged (as in N Aldo $\downarrow \mathrm{K}$ and $\uparrow$ Aldo N K), the bicarbonate concentration increased by only 6 meq/liter rather than the $22 \mathrm{meq} / \mathrm{liter}$ that was seen when both enzymes were stimulated (i.e., in the $\uparrow$ Aldo $\downarrow \mathrm{K}$ group). Thus, when both enzymes change in the same direction, alterations in acid-base composition are profound. When only one enzyme changes (or if both enzymes change, but in the opposite direction ), the effect on acid-base balance is modest.

Adrenal-intact hypokalemic rats (Figs. 4 and 5). Fig. 4 shows the relationship between plasma potassium and aldosterone in adrenal-intact hypokalemic rats with dietary potassium restriction. After $3 \mathrm{~d}$ of potassium deprivation, plasma potassium was significantly reduced $(4.1 \pm 0.1$ vs. $3.5 \pm 0.1 \mathrm{meq} / \mathrm{liter}$, $P<0.05$ ); plasma aldosterone levels fell from $35.0 \pm 1.2$ to
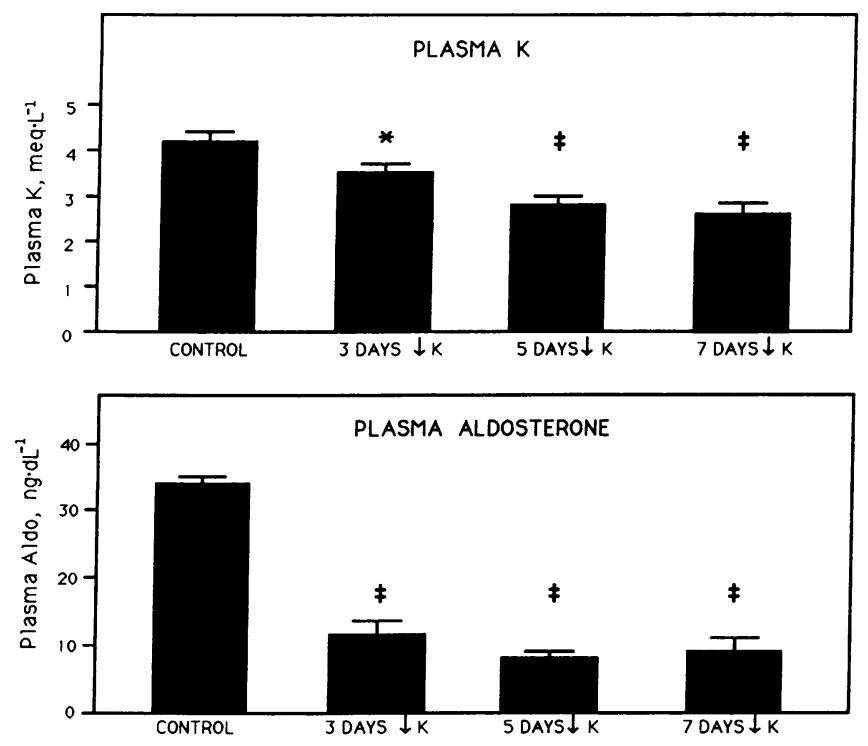

Figure 4. The effect of potassium depletion on plasma potassium and plasma aldosterone in adrenal intact rats. ${ }^{*} P 0.05,{ }^{\ddagger} P<0.005$ vs. control animals.
$11.6 \pm 1.7 \mathrm{ng} / \mathrm{dl}(P<0.005)$. After $7 \mathrm{~d}$, both parameters fell further. During this same time interval, plasma $\mathrm{HCO}_{3}^{-}$concentration was not significantly different from control animals ( $\mathrm{Ta}$ ble V). When collecting tubules were microdissected from these animals and ATPase activities were measured, the following results were obtained (Fig. 5): H/K-ATPase activity was increased $71 \pm 6.0$ and $111 \pm 5.6 \%$ in CCT and MCT, respectively, compared with controls $(P<0.005)$. By contrast, potassium depletion significantly decreased $\mathrm{H}$-ATPase activity, with a $42 \pm 2.0$ and $32 \pm 1.8 \%$ reduction in CCT and MCT, respectively, compared with controls $(P<0.005)$. Na/K-ATPase activity was decreased $35 \pm 2.2 \%$ in the CCT but in the MCT a $66 \pm 9.1 \%$ increase was noted $(P<0.005)$.

\section{Discussion}

Potassium depletion has ambiguous effects on acid-base metabolism (5). When accompanied by aldosterone excess, it is invariably associated with metabolic alkalosis. In contradistinction, potassium depletion alone is associated with a tendency to mild metabolic acidosis or alkalosis depending on the animal species studied (22-25). Potassium depletion enhances proximal acidification and ammoniagenesis, both of which increase plasma bicarbonate concentration. On the other hand, potassium depletion inhibits aldosterone release, which decreases distal acidification and, hence, plasma bicarbonate concentration (2-4).

Recently, two proton ATPases have been found in the mammalian nephron. The first is an electrogenic proton-translocating ATPase, the H-ATPase, inhibitable by NEM (6). The $\mathrm{H}$-ATPase is currently recognized as the major kidney proton pump (2). The second is an electroneutral proton-translocating ATPase, an H/K-ATPase similar to that of gastric mucosa, recently reported to reside in the mammalian kidney with the highest activity detected in the CCT $(7,8)$. The H/K-ATPase is inhibited by vanadate and SCH28080. In potassium-depleted animals $\mathrm{H} / \mathrm{K}$-ATPase activity markedly increases and appears to play an important role in distal potassium reabsorption. Recent studies suggest that the H/K-ATPase may influence distal acidification in both potassium-depleted and normokalemic animals as well as during metabolic acidosis and respiratory acidosis $(26-28)$.

Several lines of evidence have clearly demonstrated that the mineralocorticoid, aldosterone, plays a major role in regulating the renal H-ATPase. In adrenalectomized animals, H-ATPase activity is markedly reduced in mineralocorticoid sensitive nephron segments, especially in the collecting tubule (29). Indeed, chronic administration of aldosterone enhances $\mathrm{H}$ ATPase activity in normal rats (9) as well as adrenalectomized rabbits (10). Acute aldosterone administration to adrenalectomized rats also stimulates H-ATPase activity (11). On the other hand, there are scarce data about the effect of aldosterone on H/K-ATPase. A single, recent study suggested that a high physiological dose of aldosterone enhances $\mathrm{H} / \mathrm{K}$-ATPase activity in rabbit connecting tubule and CCT, but that it has no effect on enzyme activity in the MCT (30). Whether aldosterone deficiency or pharmacological doses of aldosterone affect $\mathrm{H} / \mathrm{K}-\mathrm{ATPase}$ activity is not yet known.

$\mathrm{H} / \mathrm{K}-\mathrm{ATPase}$ activity is stimulated by potassium deprivation $(7,8)$ and is inhibited by hyperkalemia (31). Studies of potassium depletion on H-ATPase activity, however, have 

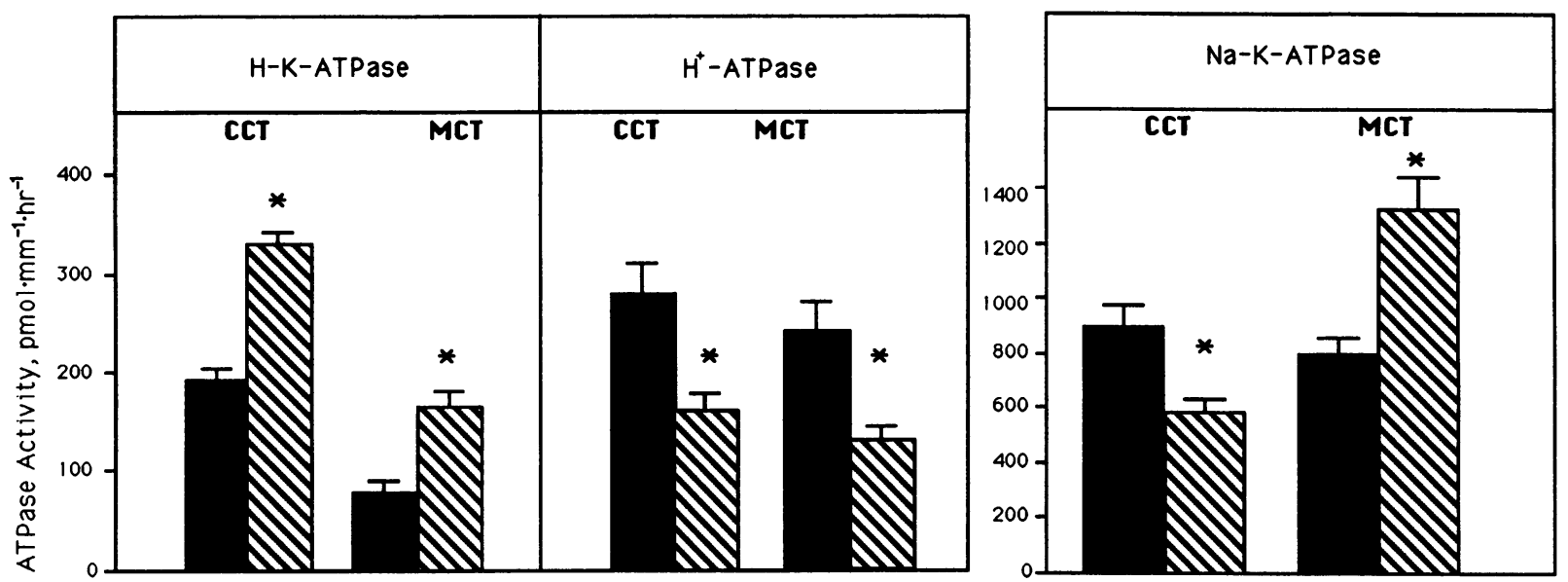

Figure 5. The effect of $7 \mathrm{~d}$ of dietary potassium depletion on H/K-ATPase, H-ATPase, and Na/K-ATPase activities in CCT and MCT in adrenal intact rats. ${ }^{*} P<0.005$ vs. control animals.

yielded conflicting results, reporting either inhibitory or stimulatory effects $(12,13)$. Changing potassium balance is complicated by profound secondary changes in plasma aldosterone, which in turn can modify H-ATPase activity. For example, the curtailment of dietary potassium intake markedly decreases serum aldosterone (reference 32 and this study). Thus, potassium depletion could decrease H-ATPase activity secondarily because of the decreased plasma aldosterone.

Aldosterone and potassium also affect $\mathrm{Na}$ /K-ATPase activity. Previous studies showed that $\mathrm{Na} / \mathrm{K}$-ATPase activity and ouabain binding were decreased in CCT and increased in MCT in potassium-depleted animals $(14,15)$. These alterations in enzyme activity could also be due to a direct effect of hypokalemia; they could also be due to an indirect effect secondary to changes in plasma aldosterone. Indeed, animals receiving high doses of exogenous aldosterone or having high endogenous aldosterone induced by potassium loading show an increase in $\mathrm{Na} / \mathrm{K}-\mathrm{ATPase}$ activity in CCT $(16,33)$. Zero aldosterone has been reported to decrease $\mathrm{Na} / \mathrm{K}$-ATPase activity in rat CCT

Table V. Metabolic Parameters in Control and Adrenal-Intact Rats after $7 d$ of Dietary Potassium Deprivation

\begin{tabular}{|c|c|c|c|}
\hline Parameter & Control & $P$ & $\begin{array}{c}\text { 7-d dietary } \\
\text { potassium } \\
\text { deprivation }\end{array}$ \\
\hline $\mathbf{P}_{\mathrm{K}}$ (meq/liter) & $4.14 \pm 0.09$ & 0.005 & $2.57 \pm 0.08$ \\
\hline $\mathrm{UV}(\mathrm{ml} / 24 \mathrm{~h})$ & $20.0 \pm 1.3$ & 0.005 & $36.7 \pm 3.4$ \\
\hline $\mathrm{FE}_{\mathrm{K}}(\%)$ & $32.7 \pm 1.6$ & 0.005 & $0.26 \pm 0.1$ \\
\hline $\mathrm{FE}_{\mathrm{Na}}(\%)$ & $0.65 \pm 0.04$ & 0.005 & $0.33 \pm 0.05$ \\
\hline $\mathrm{P}_{\mathrm{Cr}}(\mathrm{mg} \%)$ & $0.38 \pm 0.04$ & NS & $0.37 \pm 0.04$ \\
\hline $\mathrm{C}_{\mathrm{Cr}}\left(\mathrm{ml} \cdot \mathrm{min}^{-1} \cdot 100 \mathrm{~g} \cdot\right.$ body $\left.\mathrm{wt}^{-1}\right)$ & $0.98 \pm 0.07$ & NS & $0.96 \pm 0.04$ \\
\hline Muscle potassium (meq/g dry wt) & $0.44 \pm 0.03$ & 0.05 & $0.35 \pm 0.10$ \\
\hline 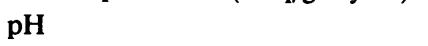 & $7.38 \pm 0.02$ & NS & $7.36 \pm 0.01$ \\
\hline $\mathrm{PCO}_{2}(\mathrm{mM})$ & $47.0 \pm 1.9$ & NS & $52.8 \pm 1.4$ \\
\hline$\left[\mathrm{HCO}_{3}^{-}\right](\mathrm{mM})$ & $23.8 \pm 0.5$ & NS & $21.7 \pm 1.0$ \\
\hline Total $\mathrm{CO}_{2}(\mathrm{mM})$ & $26.0 \pm 0.4$ & NS & $23.6 \pm 0.8$ \\
\hline
\end{tabular}

$\mathrm{UV}$, urine volume; $\mathrm{FE}_{\mathrm{K}}$, fractional potassium excretion; $\mathrm{FE}_{\mathrm{Na}}$, fractional sodium excretion. $n=6$ in each group.
(17) but to increase it in rabbit CCT (34). Again, there were concomitant alterations in potassium levels in these studies that might also have affected enzyme activity.

Therefore, the present study was conducted to explore the precise role of potassium and aldosterone on both acid-base and electrolyte composition and on collecting tubule transport enzyme activities. In adrenalectomized rats, when serum potassium was normal, H/K-ATPase activity in both CCT and MCT was similar to control regardless of aldosterone level (Fig. 1). When plasma potassium was low, enzyme activity was increased irrespective of aldosterone level. In contradistinction, when plasma potassium was high, enzyme activity was decreased, again regardless of aldosterone status. Thus, $\mathrm{H} / \mathrm{K}$ ATPase changed with plasma potassium and not with aldosterone.

With regard to $\mathrm{H}-\mathrm{ATPa}$ activity in adrenalectomized rats, enzyme activity in both CCT and MCT was similar to control at any potassium level when aldosterone was replaced physiologically (Fig. 2). When aldosterone level was low, H-ATPase activity was decreased regardless of potassium status. On the other hand, when aldosterone level was high, enzyme activity was increased irrespective of potassium level. Therefore, HATPase changed with aldosterone and not with potassium.

That aldosterone-controlled H-ATPase activity is consistent with studies reported previously $(9-11,29)$. Our study also shows that potassium has no effect on the H-ATPase. That potassium inversely modifies $\mathrm{H} / \mathrm{K}$-ATPase activity is in agreement with previous studies $(7,8)$. In addition, we show that aldosterone had no direct effect on H/K-ATPase. This latter finding is at variance with a recent study reported in abstract form that showed stimulation of $\mathrm{H} / \mathrm{K}$-ATPase activity in CCT, but not in MCT, of rabbit (30). Whether this effect is due to aldosterone directly or secondarily to changes in potassium cannot be determined from the data in the abstract.

In our adrenal intact hypokalemic rats, which had low aldosterone levels, H/K-ATPase activity was increased while $\mathrm{H}$ ATPase activity was decreased in both CCT and MCT (Fig. 5). The inhibitory effect of potassium depletion on H-ATPase is in agreement with the results reported by Khadouri et al. (12). However, our results are different from those reported by Garg and Narang (13), who showed that the enzyme was stimulated 
by potassium depletion. This discrepancy is difficult to explain because all the studies were conducted in the same animal species but may be due to technical differences in enzyme measurement. Serum aldosterone was not measured in these latter studies.

The data from the adrenal-intact potassium-depleted animals resemble those from adrenalectomized rats with 0 Aldo $\downarrow$ $K$. Both groups of animals showed low H-ATPase activity and high H/K-ATPase activity although the more profound changes were observed in the latter group. When aldosterone levels were increased to the physiological range while serum potassium was still low (i.e., in the $\mathrm{N}$ Aldo $\downarrow \mathrm{K}$ group), $\mathrm{H}$ ATPase activity increased to normal whereas $\mathrm{H} / \mathrm{K}$-ATPase activity was still high (Fig. 2). Thus, it is apparent that, in the adrenal-intact hypokalemic rat, H-ATPase is decreased because of the reduction in aldosterone.

In rats with aldosterone excess and hypokalemia, profound metabolic alkalosis occurred (Table IV). In rats with aldosterone deficiency and hyperkalemia, metabolic acidosis developed. Thus, aldosterone excess with hypokalemia was associated with stimulation of both renal proton ATPases whereas aldosterone deficiency with hyperkalemia was associated with inhibition of both enzymes. These changes may help explain the metabolic alkalosis of primary aldosteronism in which aldosterone excess and hypokalemia are combined; these changes may also explain the metabolic acidosis of aldosterone deficiency in which hypoaldosteronism and hyperkalemia are paired (5). In the first condition both renal proton ATPases are likely turned on whereas in the latter the enzymes are probably turned off. Indeed, when the changes in potassium balance and aldosterone alter the two acidifying enzymes in the opposite direction or when only one enzyme changes, the effect on acidbase balance is modest ( Table IV). Consider the adrenal-intact hypokalemic rats in which both renal proton ATPases were altered in opposite directions. Plasma bicarbonate concentration was unchanged (Table IV). Previous studies under this condition, despite differing data on renal proton ATPases, also report small alterations in acid-base composition $(12,13)$.

The stimulation of H-ATPase activity by aldosterone does not require the presence of triiodothyronine (11). It does depend on protein synthesis for it is totally abolished by actinomycin D and cycloheximide (11). At the present time, there are no data available about the intracellular signaling that regulates the renal H-ATPase. With regard to H/K-ATPase, although potassium directly controls enzyme activity, the signal transduction mechanisms again are not yet known.

The effects of aldosterone and potassium on $\mathrm{Na} / \mathrm{K}$-ATPase are different from those on the H/K-ATPase and H-ATPase. Two distinct patterns emerge. In CCT, aldosterone controls $\mathrm{Na} / \mathrm{K}$-ATPase activity (Fig. 3). Regardless of potassium status, pharmacological aldosterone enhanced enzyme activity whereas aldosterone deficiency caused a marked reduction. Potassium depletion did have a minor inhibitory effect on $\mathrm{Na} / \mathrm{K}$ ATPase in CCT. In CCT of adrenal-intact hypokalemic rats, which had low aldosterone levels, $\mathrm{Na} / \mathrm{K}$-ATPase activity was decreased. This result is in agreement with previous studies $(14,15)$, although it was not clear from them whether the alterations in enzyme activity were due to a direct effect of potassium depletion or a secondary effect of decreasing aldosterone release resulting from potassium depletion. From the results in both adrenalectomized and adrenal-intact hypokale- mic rat models, it is apparent that the reduced $\mathrm{Na} / \mathrm{K}$-ATPase activity in CCT in adrenal-intact hypokalemic rats mainly is due to a reduction in plasma aldosterone and in a minor part due to a direct effect of potassium depletion.

The stimulatory effect of aldosterone on $\mathrm{Na} / \mathrm{K}$-ATPase in CCT could indirectly enhance acidification in this tubule segment $(2,4)$. Increased $\mathrm{Na} / \mathrm{K}$-ATPase activity stimulates sodium transport, which leads to an increased potential difference and, hence, stimulation of H-ATPase. Increased $\mathrm{Na} / \mathrm{K}$ ATPase activity also leads to urinary potassium wastage and potassium depletion, which in turn activates the $\mathrm{H} / \mathrm{K}$-ATPase.

In MCT, potassium plays the major role in controlling $\mathrm{Na}$ / K-ATPase. Regardless of aldosterone activity, potassium depletion enhances enzyme activity (Fig. 3). Aldosterone deficiency, irrespective of potassium status, had a minor inhibitory effect on $\mathrm{Na} / \mathrm{K}$-ATPase. In adrenal-intact hypokalemic rats, $\mathrm{Na} / \mathrm{K}-\mathrm{ATPase}$ activity was also enhanced (Fig. 5). This result is in agreement with those reported by Hayashi and Katz (14) and by Imbert-Teboul et al. (15) but is different from those reported by Garg et al. (35), who found no effect of potassium depletion in the MCT of rabbit. Our data from both adrenalectomized and adrenal-intact animals show that potassium depletion directly stimulates $\mathrm{Na} / \mathrm{K}$-ATPase in the MCT. The effect of hypokalemia on the MCT enzyme activity supports the proposal of Hayashi and Katz (14) that the enzyme is present on the apical membrane at this site. Alternatively, hypokalemia may change enzyme affinity for potassium in this segment of the nephron. From our studies it is not possible to discern which of these two mechanisms is operative.

Previous studies in potassium-loaded rats showed $\mathrm{Na} / \mathrm{K}$ ATPase activity was increased in the CCT while it remained unchanged in the MCT $(33,35,36)$. This was mediated by an increase in aldosterone. Administration of an aldosterone antagonist was found to blunt the stimulatory effect of potassium loading on the enzyme (33). Furthermore, potassium loading had no effect on both CCT and MCT enzymes activity in adrenalectomized rats with a physiological replacement dose of aldosterone (33). The results in the 0 Aldo $\uparrow \mathrm{K}$ group and in the $\mathrm{N}$ Aldo $\uparrow \mathrm{K}$ group (Fig. 3 ) in the present study confirm these previous findings and indicate that potassium loading stimulates $\mathrm{Na} / \mathrm{K}$-ATPase in CCT via increased aldosterone release. This study does not agree with the report in adrenalectomized rabbits that potassium loading has a mineralocorticoidindependent stimulatory effect on CCT $\mathrm{Na} / \mathrm{K}$-ATPase activity (34).

In conclusion, the present study demonstrates that collecting tubule $\mathrm{H} / \mathrm{K}$-ATPase changes with potassium and not with aldosterone whereas $\mathrm{H}$-ATPase changes with aldosterone and not with potassium. When both enzymes change in the same direction, alterations in acid-base composition are profound, however, when the two acidifying enzymes change in opposite directions or when only one enzyme changes, the effect on acid-base balance is modest. The study also shows that aldosterone plays the major role in controlling $\mathrm{Na} / \mathrm{K}$-ATPase activity in CCT whereas hypokalemia exerts an aldosterone-independent stimulatory effect on enzyme activity in MCT.

\section{Acknowledgments}

We thank Ms. Christy Stroud for her excellent typographical assistance and Ms. Betty Lonis for her technical assistance. 
This work was supported in part by grants from the National Institutes of Health, No. R01-DK-36119 and No. R01-DK-36199. Somchai Eiam-Ong is the recipient of the National Kidney Foundation Fellowship Award.

\section{References}

1. Berry, C. A., and F. C. Rector, Jr. 1991. Renal transport of glucose amino acid, sodium, chloride, and water. In The Kidney. B. M. Brenner and F. C. Rector, editors. W. B. Saunders Co., Philadelphia. 245-282.

2. Alpern, R. J., D. K. Stone, and E. C. Rector, Jr. 1991. Renal acidification mechanisms. In The Kidney. B. M. Brenner and F. C. Rector, editors. W. B. Saunders Co., Philadelphia. 318-379.

3. Mujais, S. K., and A. I. Katz. 1992. Potassium deficiency. In The Kidney: Physiology and Pathophysiology. D. W. Seldin and G. Giebisch, editors. Raven Press, New York. 2249-2278.

4. Batlle, D. C., and N. A. Kurtzman. 1985. Renal regulation of acid-base homeostasis: an integrated response. In The Kidney: Physiology and Pathophysiology, D. W. Seldin and G. Giebisch, editors. Raven Press, New York. 15391565.

5. Kurtzman, N. A. 1990. Disorders of distal acidification. Kidney Int. 38:720-727.

6. Gluck, S., and Q. Al-Awqati. 1984. An electrogenic proton-translocating adenosine triphosphatase from bovine kidney medulla. J. Clin. Invest. 73:17041710.

7. Doucet, A., and S. Marcy. 1987. Characterization of K-ATPase activity in distal nephron: stimulation by potassium depletion. Am. J. Physiol. 253:F418F423.

8. Garg, L. C., and N. Narang. 1988. Ouabain-insensitive K-adenosine triphosphatase in distal nephron segments of the rabbit. J. Clin. Invest. 81:12041208.

9. Mujais, S. K. 1987. Effects of aldosterone on rat collecting tubule N-ethylmaleimide-sensitive adenosine triphosphatase. J. Lab. Clin. Med. 109:34-39.

10. Garg, L., and N. Narang. 1988. Effects of aldosterone on NEM-sensitive ATPase in rabbit nephron segments. Kidney Int. 34:13-17.

11. Khadouri, C., S. Marsy, C. Barlet-Bas, and A. Doucet. 1989. Short-term effect of aldosterone on NEM-sensitive ATPase in rat collecting tubule. Am. J. Physiol. 257:F177-F181.

12. Khadouri, C., L. Cheval, S. Marsy, C. Barlet-Bas, and A. Doucet. 1991. Characterization and control of proton ATPase along the nephron. Kidney Int. 40:S71-S78.

13. Garg, L. C., and N. Narang. 1990. Effects of low potassium diet on NEMsensitive ATPase in the distal nephron segment. Renal Physiol. Biochem. 13:129136.

14. Hayashi, M., and A. I. Katz. 1987. The kidney in potassium depletion. I. $\mathrm{Na}^{+}-\mathrm{K}^{+}$-ATPase activity and $\left[{ }^{3} \mathrm{H}\right]$ ouabain binding in MCT. Am. J. Physiol. 252:F437-F446.

15. Imbert-Teboul, M., A. Doucet, S. Marcy, and S. Siaume-Perez. 1987. Alterations of enzyme activities along the rat collecting tubule in potassium depletion. Am. J. Physiol. 253:F408-F417.

16. Mujais, S. K., M. A. Chekal, W. J. Jones, J. P. Hayslett, and A. I. Katz. 1985. Modulation of renal sodium-potassium-adenosine triphosphase by aldosterone. Effect of high physiologic level on enzyme activity in isolated rat and rabbit tubules. J. Clin. Invest. 170-176.

17. Mernissi, G. E., and A. Doucet. 1983. Short-term effects of aldosterone and dexamethasone on $\mathrm{Na} / \mathrm{K}-\mathrm{ATP}$ ase along the rabbit nephron. Pfluegers Arch. Eur. J. Physiol. 399:147-151.

18. Sabatini, S., P. K. Mehta, N. A. Kurtzman, and J. A. L. Arruda. 1981. Drug induced papillary necrosis: electrolyte excretion and nephron heterogeneity. Am. J. Physiol. 241:F14-F22.

19. Sabatini, S., M. E. Laski, and N. A. Kurtzman. 1990. NEM-sensitive ATPase activity in rat nephron: effect of metabolic acidosis and alkalosis. Am. J. Physiol. 258:F297-F304.

20. Dafnis, E., M. Spohn, N. A. Kurtzman, and S. Sabatini. 1992. Vanadate causes hypokalemic distal renal tubular acidosis. Am. J. Physiol. 262:F449-F453.

21. Ait-Mohamed, A. K., S. Marsy, C. Barlet, C. Khadouri, and A. Doucet. 1986. Characterization of N-ethylmaleimide-sensitive proton pump in the rat kidney: localization along the nephron. J. Biol. Chem. 261:12526-12534.

22. Jones, J. W., A. Sebastian, and H. N. Hulter. 1982. Systemic and renal acid-base effects of chronic dietary potassium depletion in humans. Kidney Int. 21:402-410.

23. Hulter, H. N., A. Sebastian, J. F., Sigala, J. H. Licht, R. D. Glynn, M. Schambelan, and E. G. Biglieri. 1980. Pathogenesis of renal hyperchloremic acidosis resulting from dietary potassium restriction in the dog: role of aldosterone. Am. J. Physiol. 238:F79-F91.

24. Hays, S. R., D. W. Seldin, J. P. Kokko, and H. R. Jacobson. 1986. Effect of $\mathrm{K}$-depletion on $\mathrm{HCO}_{3}$ transport across rabbit collecting duct segments. Kidney Int. 29:368 A. (Abstr.)

25. McKinney, T. D., and K. K. Davidson. 1987. Effect of potassium depletion and protein intake in vivo on renal tubular bicarbonate transport in vitro. Am. J. Physiol. 252:F509-F516.

26. Cheval, L., C. Barlet-Bas, C. Khadouri, E. Feraille, S. Marsy, and A. Doucet. 1991. $\mathrm{K}^{+}$-ATPase-mediated $\mathrm{Rb}^{+}$transport in rat collecting tubule: modulation during $\mathrm{K}^{+}$deprivation. Am. J. Physiol. 260:F800-F805.

27. Gifford, J. D., L. Rome, and J. H. Galla. 1992. $\mathrm{H}^{+}-\mathrm{K}^{+}$-ATPase activity in rat collecting duct segments. Am. J. Physiol. 262:F692-F695.

28. Komatsu, Y., and L. C. Garg. 1991. Stimulation of ouabain-insensitive $\mathrm{K}-\mathrm{ATPase}$ in the rat medullary collecting duct by potassium depletion and metabolic acidosis. FASEB (Fed. Am. Soc. Exp. Biol.) J. 5:A752. (Abstr.)

29. Khadouri, C., S. Marsy, C. Barlet-Bas, and A. Doucet. 1987. Effect of adrenalectomy on NEM-sensitive ATPase along rat nephron and on urinary acidification. Am. J. Physiol. 253:F495-F499.

30. Garg, L. C., and N. Narang. 1990. Effects of aldosterone on ouabain-insensitive K-ATPase activity in rabbit nephron segments. J. Am. Soc. Nephrol. 1:684. (Abstr.)

31. Garg, L. C., and N. Narang. 1989. Suppression of ouabain-insensitive K-ATPase activity in rabbit nephron segments during chronic hyperkalemia. Renal Physiol. Biochem. 12:295-301.

32. Linas, S. L., L. N. Peterson, R. J. Anderson, G. A. Aisenbrey, F. R. Simon, and T. Berl. 1979. Mechanism of renal potassium conservation in the rat. Kidney Int. 19:36-48.

33. Mujais, S. K., M. A. Chekal, J. P. Hayslett, and A. I. Katz. 1986. Regulation of renal $\mathrm{Na}^{+}-\mathrm{K}^{+}$-ATPase in the rat: role of increased potassium transport. Am. J. Physiol. 251:F199-F207.

34. Garg, L. C., and N. Narang. 1985. Renal adaptation to potassium in adrenalectomized rabbit. Role of distal tubular sodium-potassium adenosine triphosphate. J. Clin. Invest. 76:1065-1070.

35. Garg, L. C., S. Mackie, and C. C. Tischer. 1982. Effect of low potassiumdiet on Na/K-ATPase in rat nephron segments. Pfluegers Arch. Eur. J. Physiol 394:113-117

36. Doucet, A., and A. I. Katz. 1980. Renal potassium adaptation: Na/KATPase activity along the nephron after chronic potassium loading. Am. J. Physiol. 238:F380-F386. 